\title{
Passive Immunization of Anti bZP3 (Zone Pellucida3) in Wistar Rat (Rattus novergicus) and Mouse (Mus musculus)
}

\author{
Y. Pantiwati \\ Department of Biology Education, Faculty of Teacher Training and Education, \\ University of Muhammadiyah Malang \\ Raya Tlogomas 246 Malang 65144, Indonesia \\ (Received 13-01-2012; Reviewed 10-07-2012; Accepted 28-12-2012)
}

\begin{abstract}
This study was aimed at comparing the influence of anti bZP3's passive immunization on antianti bZP3's titer and pregnancy level on Wistar rats and mice. This study employed factorial design experiment with completely randomized design. The first factor was immunogenic type. The treated rats were immunized with $100 \mu \mathrm{L}$ anti bZP3 in $100 \mu \mathrm{L}$ Complete Freund's Adjuvant (CFA), while the treated mice were injected with $50 \mu \mathrm{L}$ anti bZP3 in $50 \mu \mathrm{L}$ CFA. Control Wistar rats and mice were immunized with CFA and Incomplete Freund's Adjuvant (IFA) without anti bZP3. The second factor was animal type. The third factor was the length of serum incubation, i.e. 38, 49, 63, 86, 100, and 126 d. Dot blot on the treated Wistar rats and mice showed positive response proven by blue gradation; pre-immune mice as well as control Wistar rats and mice showed negative response proven by white gradation. The highest antibody titer in treated mouse serum was shown in $63 \mathrm{~d}$ incubation. The pregnancy on treated mice, control mice and Wistar rat occurred $100 \%$ until day 126 ; while the failure percentage on the treated mice was $4.5 \%$. The pregnancy on treated mice occurred in $86 \mathrm{~d}$ incubation (1 rat), $100 \mathrm{~d}$ incubation (1 rat), and $126 \mathrm{~d}$ incubation (3 rats). Effective passive immunization on similar hospes occurred until day 63; while different hospes was ineffective. Antibodi anti-bZP3 was potential as a contraception through passive immunization on similar hospes.
\end{abstract}

Key words: passive immunization, anti bZP3 (bovine Zona Pellucida)

\section{ABSTRACT}

Tujuan penelitian adalah membandingkan pengaruh imunisasi pasif anti bZP3 terhadap titer anti-anti bZP3 dan tingkat kebuntingan antara tikus putih dan mencit. Metode penelitian menggunakan rancangan acak lengkap pola faktorial. Faktor pertama jenis imunogen, imunisasi pada tikus perlakuan dengan imunogen $100 \mu \mathrm{l}$ anti bZP3 dalam $100 \mu \mathrm{l}$ Complete Freund's Adjuvant (CFA), sedang mencit perlakuan diinjeksi $50 \mu \mathrm{l}$ anti bZP3 dalam $50 \mu \mathrm{l} \mathrm{CFA.} \mathrm{Tikus} \mathrm{dan} \mathrm{mencit} \mathrm{kontrol}$ diimunisasi CFA dan Incomplete Freund's Adjuvant (IFA) tanpa anti bZP3. Faktor kedua jenis hewan, yaitu tikus dan mencit, dan faktor ketiga lama inkubasi serum meliputi hari ke-38, 49, 63, 86, 100, dan 126. Hasil dot blot pada tikus dan mencit perlakuan menunjukkan respon positif dengan noda warna biru, sedang tikus dan mencit pre-imun maupun tikus dan mencit kontrol respon negatif dengan noda warna putih. Titer antibodi tertinggi pada serum mencit perlakuan dengan lama inkubasi 63 hari. Mencit perlakuan, mencit dan tikus kontrol terjadi kebuntingan 100\% sampai hari ke-126, sedangkan tikus perlakuan mengalami kegagalan 4,5\%, kebuntingan terjadi pada inkubasi 86 hari (1 ekor), 100 hari (1 ekor), dan 126 hari (3 ekor). Imunisasi pasif efektif pada hospes yang sama sampai pada hari ke 63, sebaliknya hospes berbeda tidak efektif. Antibodi anti-bZP3 mampu menekan efektivitas fertilisasi, sehingga berpeluang sebagai bahan kontrasepsi melalui imunisasi pasif atau imunokontrasepsi pada hospes yang sama.

Kata kunci: imunisasi pasif, anti bZP3 (bovine Zona Pellucida)

${ }^{*}$ Corresponding author:

E-mail: yuni_pantiwati@yahoo.co.id 


\section{INTRODUCTION}

Pregnancy could be prevented by using contraception methods that can be applied for both men and women. Some contraception methods are apparently considered less effective and safe as they are exposed to a number of side effects. Recent studies found that zona pellucida (ZP) has shown to possess a strong immunogenicity. Therefore, a number of experiments have been conducted to develop a contraceptive vaccine using zona pellucida antigens (Koyama et al., 2005). Besides, it is also possible to utilize ovary waste from animal slaughtering houses.

Prasad et al. (2000) states that fertilization could be prevented by using ZP glycoprotein. Basically, glycoprotein recognizes sperm. The immunization with $\mathrm{ZP}$ glycoprotein molecule induces the growth of antibody for $\mathrm{ZP}$ that would inhibit the interaction between $\mathrm{ZP}$ and spermatozoa. Resulting in infertility, ZP could be used as contraception.

ZP3 is potential for immune-contraception target. Sumitro \& Aulanni'am (2001) conducted a study on this field by injecting female Wistar rats with bZP3 (bovine
Zona Pellucida) which later produce anti-bZP3. Bovine Zona Pellucida, a specific antigen isolated from cow oocytes, is proven to be reversible and effective to stimulate the production of anti-bZP3. Immunologic reaction between anti-bZP3 and ZP inhibits the interaction between ovum and spermatozoa, and thus no fertilization occurs.

The high antigen characteristics of bZP3 molecule immunized actively, and the nature of $\mathrm{ZP}^{\prime} \mathrm{s}$ crossed reaction requires further studies about the usage of $\mathrm{ZP}$ as immune-contraception. Therefore, further research about passive immunization to female Wistar rats and mice by using anti bZP3 produced by Wistar rat is needed. Female Wistar rats and mice are often used in research as they have high fertilities that support efficacy of reproduction. Nearly $90 \%$ scientific research use Wistar rats and mice as experimental animals because they grow up faster, do not show any seasonal marriage, and are easy to breed. In addition, they belong to the same family, Muridae (Moore, 2000). This study was aimed at comparing the effectiveness of passive immunization with anti bZP3 in Wistar rats and mice on antibody titer and pregnancy level.

Table 1.The experimental design

\begin{tabular}{|c|c|c|c|c|c|c|}
\hline \multirow[b]{2}{*}{ Immunogen type } & \multirow[b]{2}{*}{ Species type } & \multicolumn{5}{|c|}{ Harvest time $(\mathrm{d})$} \\
\hline & & $\begin{array}{l}\text { After I immuni- } \\
\text { zation (day to 1) }\end{array}$ & $\begin{array}{l}\text { After I booster } \\
\text { (day to } 28 \text { ) }\end{array}$ & $\begin{array}{l}\text { After II booster } \\
\text { (day to 56) }\end{array}$ & $\begin{array}{l}\text { After III booster } \\
\text { (day to 93) }\end{array}$ & Harvest to- \\
\hline \multirow[t]{12}{*}{ Control (adjuvant) } & \multirow[t]{6}{*}{ Wistar rat } & 38 & 10 & - & - & 1 \\
\hline & & 49 & 21 & - & - & 2 \\
\hline & & 63 & 35 & 7 & - & 3 \\
\hline & & 86 & 58 & 30 & - & 4 \\
\hline & & 100 & 72 & 44 & 7 & 5 \\
\hline & & 126 & 98 & 70 & 33 & 6 \\
\hline & \multirow[t]{6}{*}{ Mouse } & 38 & 10 & - & - & 1 \\
\hline & & 49 & 21 & - & - & 2 \\
\hline & & 63 & 35 & 7 & - & 3 \\
\hline & & 86 & 58 & 30 & - & 4 \\
\hline & & 100 & 72 & 44 & 7 & 5 \\
\hline & & 126 & 98 & 70 & 33 & 6 \\
\hline \multirow{12}{*}{$\begin{array}{l}\text { Treated (Ab in } \\
\text { adjuvant) }\end{array}$} & \multirow[t]{6}{*}{ Wistar rat } & 38 & 10 & - & - & 1 \\
\hline & & 49 & 21 & - & - & 2 \\
\hline & & 63 & 35 & 7 & - & 3 \\
\hline & & 86 & 58 & 30 & - & 4 \\
\hline & & 100 & 72 & 44 & 7 & 5 \\
\hline & & 126 & 98 & 70 & 33 & 6 \\
\hline & \multirow[t]{6}{*}{ Mouse } & 38 & 10 & - & - & 1 \\
\hline & & 49 & 21 & - & - & 2 \\
\hline & & 63 & 35 & 7 & - & 3 \\
\hline & & 86 & 58 & 30 & - & 4 \\
\hline & & 100 & 72 & 44 & 7 & 5 \\
\hline & & 126 & 98 & 70 & 33 & 6 \\
\hline
\end{tabular}




\section{MATERIALS AND METHODS}

This study employed factorial design experiment with completely randomized design. The first factor was immunogenic type [immunization only with adjuvant (control) and immunization with anti bZP3 in adjuvant (treatment)]. The second factor was animal type (female Wistar rat and female mice), and the third factor was the length of serum incubation (38, 49, 63, 86, 100, and 126 $\mathrm{d}$ after anti-bZP3 immunization). The total of treatment was $2 \times 2 \times 6=24$ treatment combinations; each of which was repeated three times, as shown in Table 1.

Population in this study included female Wistar rats (Rattus norvegicus) and female mice (Mus musculus). Samples in this study included 36 female Wistar rats (R. norvegicus) aged $3 \mathrm{mo}$ and weight of $250 \mathrm{~g}$, and 36 female mice (M. musculus) aged $2 \mathrm{mo}$, with the weight of $30 \mathrm{~g}$. The samples were taken from Pusvetma Surabaya. As the population was homogenous, the samples were taken randomly.

Immunization was done by subcutaneous injection in several locations of the body. The first immunization was conducted on the treatment Wistar rats with 100 $\mu \mathrm{l}$ immunogen anti bZP3 in $100 \mu \mathrm{L}$ Complete Freund's Adjuvant (CFA); while the treatment mice were injected with $50 \mu \mathrm{L}$ of anti bZP3 in $50 \mu \mathrm{L}$ CFA. The repeated immunization was done on the following $10 \mathrm{~d}$ by increasing $100 \mu \mathrm{L}$ anti bZP3 in $100 \mu \mathrm{L}$ Incomplete Freund's Adjuvant (IFA) for the treatment Wistar rats; while the treatment mice were injected with $50 \mu \mathrm{L}$ anti bZP3 in 50 $\mu \mathrm{L}$ IFA. This repeated immunization is by definition a booster. Control Wistar rats and mice were only immunized by CFA and IFA without anti bZP3. The schedule of booster II and III is shown in Table 1 and Table 2 .

Serum harvesting was done by cutting the animals' tail at about $50 \mathrm{~mm}$ from the tip of tail. The blood of the Wistar rats was taken $1000 \mu \mathrm{L}$, while the blood of mice was taken $500 \mu \mathrm{L}$. Serum harvesting was done six times, on day $38,49,63,86,100$, and 126 . The harvesting was done on day 38 for the reason that the animals had just been treated with booster I (10 d). The next harvesting was done on day 49 because on that day the testing animals were about to get booster II. The serum harvesting was done on day 63 or seven days after booster II. It was expected that the titer level would be high. The next serum harvesting was done on day 86 for the reason that the animals had been treated with booster II for thirty days, and that it was a short period before booster III. Then, the serum harvesting was done on day 100 or seven days after booster III. Last, the serum harvesting day was done on day 126 or thirty-three days after booster III (Figure 1).

Blood taken based on its incubation period was kept for $10 \mathrm{~min}$ at room temperature. The blood was then centrifuged at $1500 \mathrm{rpm}$ for $15 \mathrm{~min}$ at room temperature. Precipitate was discarded; while supernatant as serum was transferred to eppendorf and kept at the temperature of $-20^{\circ} \mathrm{C}$ before purification. In purification process, serum was added with SAS $50 \%$ in the ratio of $1: 1$, homogenized by using vortex, and incubated for several minutes at $4{ }^{\circ} \mathrm{C}$. After that, the serum was centrifuged at

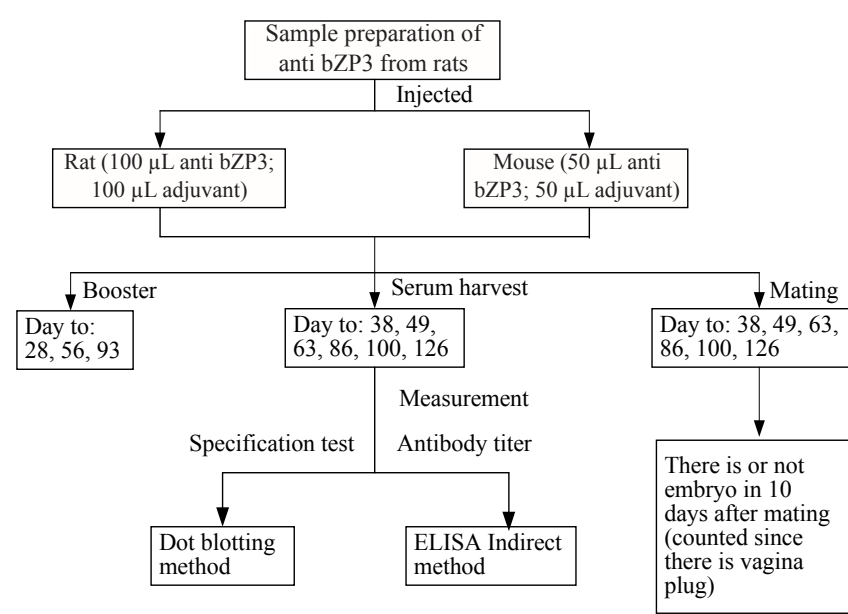

Figure 1. Scheme of research procedure

Table 2. Immunization schedule and harvest time at Wistar rat and mouse

\begin{tabular}{|c|c|c|c|}
\hline \multirow{2}{*}{ Time (d) } & \multicolumn{2}{|c|}{ Treatment at animal } & \multirow{2}{*}{ Explanation } \\
\hline & Control & Treatment & \\
\hline Day to 0 & Blood taking & - & Pre immune \\
\hline Day to 1 & CFA injection & Injection of anti bZP3 in CFA (1:1) & - \\
\hline Day to 28 & IFA injection & Injection of anti bZP3 in IFA (1:1) & Booster of I \\
\hline Day to 38 & Blood taking & Blood taking & Mating; pregnancy test \\
\hline Day to 49 & Blood taking & Blood taking & Mating; pregnancy test \\
\hline Day to 56 & IFA injection & Injection of anti bZP3 in IFA (1:1) & Booster of II \\
\hline Day to 63 & Blood taking & Blood taking & Mating; pregnancy test \\
\hline Day to 86 & Blood taking & Blood taking & Mating; pregnancy test \\
\hline Day to 93 & IFA injection & Injection of anti bZP3 in IFA (1:1) & Booster of III \\
\hline Dayto 100 & Blood taking & Blood taking & Mating; pregnancy test \\
\hline Day to 126 & Blood taking & Blood taking & Mating; pregnancy test \\
\hline
\end{tabular}

Note: CFA= Complete Freund's Adjuvant, IFA : Incomplete Freund's Adjuvant 
$3000 \mathrm{rpm}$ for $30 \mathrm{~min}$ at $4{ }^{\circ} \mathrm{C}$. Supernatant was discarded. Precipitate was washed with SAS 50\% (10 times as much as serum volume), homogenized by using vortex, and centrifuged at $3000 \mathrm{rpm}$ for $30 \mathrm{~min}$ at $4{ }^{\circ} \mathrm{C}$. Precipitate was added with $0.05 \mathrm{M}$ phosphate buffer $\mathrm{pH} 7$ at the same volume, and dialyzed in $0.01 \mathrm{M}$ phosphate buffer $\mathrm{pH} 7$ for $12 \mathrm{~d}$ at $4{ }^{\circ} \mathrm{C}$.

Antibody labeling was done by the conjunction of anti bZP3 as the results of anti bZP3 inductions to the animals based on their own incubation periods. Antigen specificity was done using Dot Blotting method. The change or degradation of colors was believed to be some indications to predict the existence of anti bZP3 in testing animal serum. The data were analyzed descriptively and qualitatively.

The result of antibody titer to the anti bZP3 was characterized based on the value of antibody titer using ELISQE technique and the method of indirect ELISA. The result was analyzed in descriptive to detect the distribution of each combination of the tested animals, and Anova to compare the effect of treatment combination to the free variables. If the result of Anova is found to be different, the test will be continued by using Duncan's test (Sugiono, 2009).

Pregnancy test was conducted one night after mating, vagina plug was performed to ensure fertilization. When there was a plug, the surgery would be conducted on the following $10 \mathrm{~d}$ to see the existence of embryo. The pregnancy rate was obtained from dividing the number of pregnant treated animals by the number of mated animals in the treated group and was then multiplied by $100 \%$.

\section{RESULTS AND DISCUSSION}

The result of specification test to the IgG anti bZP3 to antibody of IgG anti bZP3 in the Wistar rat and mouse serum induced by IgG anti bZP3 of Wistar rats showed a positive reaction with appearance of blue stain during incubation day 38, 49, 63, 86, 100, and 126 with 1/100 and $1 / 200$ dilution. The blue stain degradation occurred in both dilutions; the $1 / 100$ dilution had darker blue stain than $1 / 200$ dilution. Wistar rat serum incubated in $38 \mathrm{~d}$ appeared to have stronger blue stain compared to the other serum with different period of incubation. The lightest blue stain could be seen in the serum incubated for $126 \mathrm{~d}$. In other case, generally the blue stain of mice was strong, but at $63 \mathrm{~d}$ incubation appeared to show the strongest blue (Figure 2). Blue stain was the complex of primary antibody antigen-antibody of secondary, labeled by alkaline phosphatase (AP) with western blue substrate in dot blotting result. Promega (2006) explained that secondary antibody-alkaline phosphatase conjugate recognized and was bound to the primary antibody. Color development substrate was added and was acted upon by the alkaline phosphatase $(\mathrm{AP})$, resulting in a localized precipitate on the membrane. Besides, IgG anti bZP3 from the induced Wistar rats was recognized by the Wistar rats. It was not consideredasforeignsubstancesand IgG anti bZP3 still functioned as the antibody. In dot blotting method, the blue stain appeared because the Wistar rats recognized bZP3; while the mice had im- mune reaction because IgG anti bZP3 was assumed to be foreign substancesso it produced IgG anti IgG anti bZP3 which also recognized antibody of IgG anti bZP3. This indicated that antigen was recognized by anti bZP3.

Control Wistar rats and mice induced only with adjuvant showed negative reaction in the incubation period of $38,49,63,86,100$, and $126 \mathrm{~d}$. It was shown by one single color, white. It existed not onlyin $1 / 100$ dilution, but also $1 / 200$ dilution. Wistar rat and pre-immune mouse serum, which was not induced with adjuvant and IgG anti bZP3, also showed white color (Figure 2). White color showed negative response because it did not form a complex of antigen - primary antibody - secondary antibody. This research used IgG antigen anti bZP3 of Wistar rat, antibody of IgG anti bZP3 as primary antibody, and anti rat IgG alkaline phosphatase (AP) conjugated as secondary antibody. White color also indicated that there was no binding complex between antigen-antibody primer-secondary antibody as there was not specific reaction between IgG anti bZP3 and antibody of control animal serum. As control animals were only injected with adjuvant, it had no and did not produce antibody that could recognize bZP3 and also antibody of IgG anti bZP3. As a result, there was no binding between primary antibodies and labeled secondary antibody. Moreover, the addition of substrate did not generate any reaction to the color. The serum of pre-immune Wistar rats and mice also resulted in white color; and the complex binding between antigen - primary antibody - secondary antibody did not appear.

Serum of mice appeared to be darker in blue than that of Wistar rat serum. It was because mice formed IgG anti IgG anti bZP3 and it had higher antibody titer than Wistar rat titer; while Wistar rats did not respond to form IgG anti IgG anti bZP3 because IgG anti bZP3 was not assumed asforeignsubstances. IgG anti bZP3 remained with its function as antibody. Therefore, the longer the period of incubation antibody titer, the less bZP3 appeared and the lighter the blue stain was. Wistar rats and mice with antibody $1 / 100$ dilution had darker blue stain compared to dilution 1/200.

The antibody titer in the interaction of test animal type, type of injection, and the period of incubation were different. Based on the average value of antibody titer, it seemed that the highest antibody titer of adjuvant antibody of the injected mouse was in the incubation period of $63 \mathrm{~d}$. Treated Wistar rats had smaller antibody serum titer than that of treated mice. This was because the IgG anti bZP3 of Wistar rats injected to the other Wistar rats remained with its function as antibody because IgG anti bZP3 of Wistar rats was not considered as foreignsubstances, so Wistar rats did not form IgG anti IgG anti bZP3. According to Baxter (2007), passive immunity refers to the process of providing IgG antibodies to protect against infection; it gives immediate, but short-lived protection from several weeks to 3 or 4 mo at most. Passive immunity is usually classified as natural or acquired. Delves \& Roitt (2005) also explain that passive administration of antibody has the advantage from its immediate effect, rather than having to wait for the immune response to build up before a contraceptive effect is obtained as in the case ofconventional immu- 


\begin{tabular}{|c|c|c|c|c|}
\hline \multirow{2}{*}{$\begin{array}{c}\text { Antigen } \\
\text { concentrate }\end{array}$} & \multicolumn{4}{|c|}{ Serum deluting period of 63 d after immunization } \\
\cline { 2 - 5 } & $1 / 100$ & $1 / 100$ & $1 / 200$ & $1 / 200$ \\
\hline \multirow{2}{*}{ Blank } & & & & \\
\hline $1 / 200$ & & & & \\
\hline \multirow{2}{*}{ Blank } & & & & \\
\hline
\end{tabular}

Figure 2. Specification test for $63 \mathrm{~d}$ incubation period, yellow color for Wistar rats and red color for mice

nization. Furthermore, there is no requirement to break immunological tolerance, and individual variations in immune responses, therefore the level and duration of effectiveness are eliminated. However, passive immunization is likely to be more expensive and requires repeated administration.

During incubation period of day 86, 100, and 126, the antibody titer was low and specification test also showed that the longer the incubation period, the more blue stain attenuated (Figure 3). The less antibody of bZP3 available would decrease the ability to block the reaction between $\mathrm{ZP}$ with spermatozoa. It caused the ZP3 to bind itself with specific protein of spermatozoa and stimulate initiative reaction of acrosome that resulted in fertilization led to pregnancy. Therefore, passive immunization with IgG anti bZP3 of Wistar rats in similar hospes, which was Wistar rat, was effective to inhibit fertilization until day 63. The degradation of antibody titer anti bZP3 could be followed by the degradation of antibody ability to block the ovum, so it enabled the

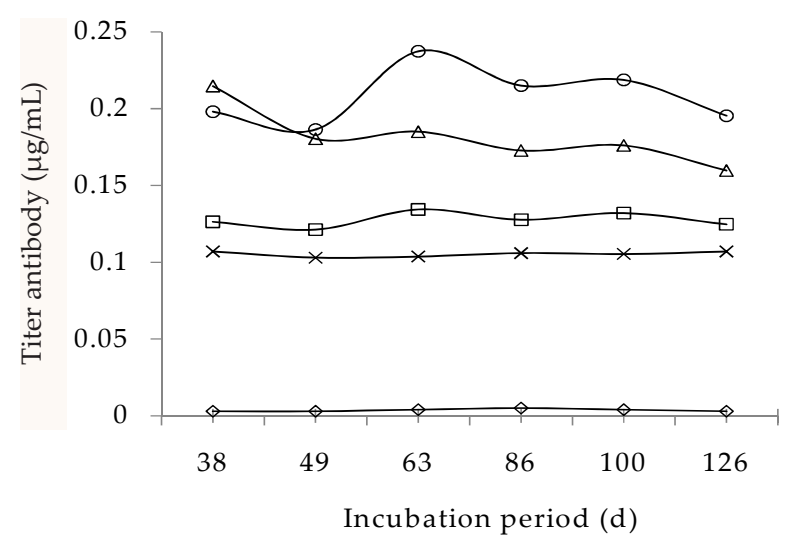

Figure 3. Titer antibody of Wistar rat and mouse for pre-immune $(-\diamond-)$ : control Wistar rat (- $\square-)$; treated Wistar rat $(-\Delta-)$; control mouse (-x-); treated mouse (-o-). binding of $\mathrm{ZP}$ with spermatozoa by involving receptor existing not only in oocytes, but also the spermatozoa.

Based on its role, zona pellucida is an extracellular matrix that surrounds the oocyte and early embryo. It has primarily three or four glycol-proteins with various functions during fertilization and pre-implantation development. The protein encoded by the gene is a structure component of the zona pellucida and functions in primary binding and sperm acrosome reactions. Gupta et al. (2011) also argued that zona pellucida glycol-proteins, by virtue of their critical role in fertilization, have been proposed as candidate antigens for the development of contraceptive vaccines.

There were 36 mated mice, 18 control and 18 treated mice, and 36 mated Wistar rats, 18 control and 18 treated Wistar rats. Control Wistar rats, treated mice, and control mice showed $100 \%$ pregnancy from the period of incubation of 38 until $126 \mathrm{~d}$. The pregnancy rate on treated Wistar rats indicated different results in every period of incubation. The pregnancy rate of treated Wistar rats

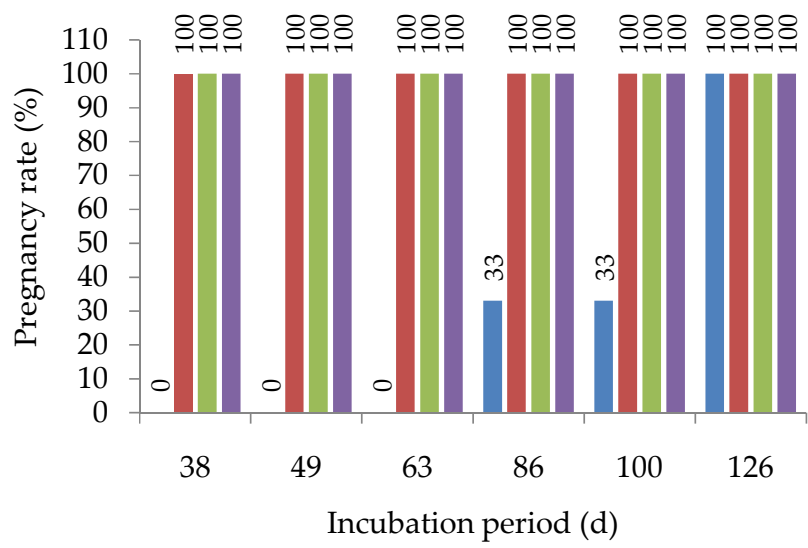

Figure 4. Test result of pregnancy at wistar rat and for pre-immune; control Wistar rat $(\square)$; treated Wistar rat $(\square)$; control mouse $(\nabla)$; treated mouse $(\square)$. 
during the incubation period of 38,49 , and $63 \mathrm{~d}$ was $0 \%$; during the incubation period of 86 and $100 \mathrm{~d}$ was 33\%; and showed $100 \%$ pregnancy rate in day 126 . The failure started to occur in day 126 (Figure 4).

Treated Wistar rats induced with IgG anti bZP3 were not pregnant during the incubation period of 38 , 49 , and $63 \mathrm{~d}$; but on day 86 they began to be pregnant followed by the treated Wistar rats with the length of incubation 100 and $126 \mathrm{~d}$. This was because the IgG anti bZP3 of Wistar rats injected to other Wistar rat remained with its function as antibody; IgG anti bZP3 could block the reaction between $\mathrm{ZP}$ and spermatozoa; while $\mathrm{ZP}$ contained glicoprotein that recognized sperm, so the receptor became inactive at recognizing sperm. Process of reaction of acrosom did not occur and it disturbed the fertilization process. The disturbance would make fertilization impossible. According to the finding of Barber \& Fover (2000), antibody of IgG anti bZP3 in animal that experienced vaccination started to bind with the group of glycoprotein ZP3 (sperm receptor) of ZP in follicle de Graff. In this case, the first goal of antibody was the surface carbohydrate residue. Antibody of anti bZP3 also blocked the fertilization by hindering the treads in charge of inducing the acrosome reaction and this involved some parts of ZP protein. Antibody at the same species remained with its function and tied the ZP3 receptor up; therefore, it was predicted that it would cause the failure of fertilization. While antibody of different species caused immune reaction to solve the entering of foreign $\operatorname{IgG}$, the clients would be able to do fertilization and pregnant (Gwatkin, 1982).

Mice induced with IgG anti bZP3 of Wistar rats became pregnant because in mice, there was a reaction of immunity to reject foreign IgG. Therefore, IgG anti bZP3 was a foreign object capable of showing immune response to specific antibody, such as IgG anti IgG anti bZP3. IgG anti IgG anti bZP3 formed by mice after being immunized with IgG anti bZP3 of Wistar rats was unable to hinder the binding process of sperm or could not block the reaction between $\mathrm{ZP}$ and spermatozoa, while $\mathrm{ZP}$ contained glycoprotein (sperm receptor) which recognized sperm. It made the receptor actively recognize sperm. The reactive process of acrosome occurred; there was nothing that troubled the process of fertilization. As a result, fertilization occurred. According to El-Mestrah et al. (2002), zone pellucida is a thick extracellular coat that surrounds growing oocytes, ovulated eggs, and pre-implantation embryos in mammal. The ZP contains receptor that mediates initial interaction between sperm and eggs a prelude to fertilization; it also mediates the relative species-specificity during gamete interaction, prevents polyspermy, and protects the developing embryo prior to implantation. Wassarman et al. (2004) explained that zone pellucida of mammals in general contained three types of constituent glycosidase protein (Zpl, ZP2, and Zp3) which play important roles in fertilization as primary receptor reaction of spermatozoa recognition. Successful fertilization depends on the ability of sperm to penetrate extra cellular matrix surrounding eggs. In Wistar rats: ZP3 allows species-specific sperm binding, ZP2 mediates subsequent sperm binding, and ZP1 cross-links ZP2 and ZP3. Rankin et al. (2001) also explained that the ZP plays important roles in oocyte development fertilization and early embryo development.

The advantage of using active immunization is that it has reversible fertilities longer than passive immunization. Passive immunization relates to the existing substances; therefore, it works quickly, but it has no stimulation for the next production. It only has short-terminfluence. The other advantage of using active immunization is that it is effective for the immune-contraception in some different animals or species, so it has wide character of crossed reactions. However, it could possibly generate negative effects as genetically there are differences in species of antigen source from the induced hospes. There is a big chance for side effects. Passive immunization could only be effectively used for the same hospes within the same species. There is an equal genetic nature between species of antigen source and hospes, and thus negative effect could be prevented. In other words, passive immunization is more effective for immune-contraception. In ssence, contraceptive vaccines must be effective, long lasting, cheap and readily applicable, and have no unacceptable side effects (Grandy \& Rutberg, 2002).

\section{CONCLUSION}

Passive immunization with antibody bZP3 on female Wistar rats and mice showed different effects. Effective passive immunization on similar hospes occurred until day 63; while different hospes was ineffective, proven by pregnancy. Antibodi bZP3 was proven to inhibit fertilization, and was potential as a contraception through passive immunization or immune-contraception on similar hospes.

\section{ACKNOWLEDGMENT}

Thanks to research group team bZP3 of biomedical laboratory-UNIBRAW and other parties for the kind assistance so this research and the writing process of the document could be done very well.

\section{REFERENCES}

Barber, M. R. \& R. A. Fover-Hosken. 2000. Evaluation of somatic and reproductive immunotoxic effects of the porcine zona pellucida vaccination. J. Exp. Zoo 286: 641-646. http:// dx.doi.org/10.1002/(SICI)1097-010X(20000501)286:6<641:: AID-JEZ11>3.0.CO;2-\#

Baxter D. 2007. Active and passive immunity, vaccine types, excipients and licensing. Occup Med (Lond). 57: 552-556. http://dx.doi.org/10.1093/occmed/kqm110

Delves, P. J. \& I. M. Roitt. 2005. Vaccines for the control of reproduction--status in mammals, and aspects ofcomparative interest. Dev Biol (Basel). 121:265-273

Grandy, J. W. \& A. T. Rutberg. 2002. An animal welfare view of wildlife contraception. Reproduction 60:1-7.

Gupta, S. K., V. A. Srinivasan, P. Suman, S. Rajan, S. B. Nagendrakumar, N. Shrestha, P. Joshi, \& A. K. Panda. 2011. Contraceptive vaccines based on the zona pellucida glycoproteins for dogs and other wildlife population management. Am. J. Reprod. Immunol. 66: 51-62. http://dx.doi. org/10.1111/j.1600-0897.2011.01004.x

Gwatkin, R. B. L. 1982. Receptor for Sperm on the mammalian 
ovum. MTP Press Limited International Medical Publisher 1-9.

El-Mestrah, M., P. E. Castle, G. Borossa, \& F. W. Kan. 2002. Subcellular distribution of ZP1, ZP2, and ZP3 glycoproteins during folliculogenesis and demonstration of their topographical disposition within the zona matrix of mouse ovarian oocytes. Biol Reprod 66: 866-876. http://dx.doi. org/10.1095/biolreprod66.4.866

Koyama, K., A. Hasegawa, N. Mochida, \& G. Calongos. 2005. Follicular dysfunction induced by autoimmunityto zona pellucida. Reprod. Biol. 5: 269-78.

Moore, D. M. 2000. Rats and mice: Biology V-9041. The University of Washington Health Sciences Center for Educational Resources and the American College of Laboratory Animal Medicine.

Prasad, S. V., S. M. Skinner, C. Carino, N. Wang, J. Cartwright, \& B. S. Dunbar. 2000. Sructure and function of protein of the mammalian zona pellucida. Cell Tissues Organs 166: 148-164. http://dx.doi.org/10.1159/000016730

Promega. 2006. Immunological detection. Technical Bulletins and Manual: 293-304.

Rankin, T. L., M. O’Brien, E. Lee, K. Wigglesworth, J. Eppig, \& J. Dean. 2001. Defective zonae pellucidae in Zp2-null mice disrupt folliculogenesis, fertility, and development. Development 128:1119-1126.

Sugiono. 2009. Research of Statistic. Alfabeta, Bandung.

Sumitro, S. B. \& Aulanni'am. 2001. Zona Pellucida 3 (ZP3) has proper biochemical properties to be considered as candidate antigen for immunocontraceptive vaccine. Reprotech.1: 51-53.

Wassarman, W. M., L. Jovine, \& E. S. Litscher. 2004. Mouse zona pellucida genes and glycoproteins. Cytogenet Genome Res. 105:228-234. http://dx.doi.org/10.1159/000078193 